IRSH 60 (20I 5), pp. 379-4I I doi:10.10I7/S00208590I 5000528

(C) 2015 Internationaal Instituut voor Sociale Geschiedenis

\title{
Becoming Workers? Strikes by Hotel and Restaurant Staff in Italy (1902-1923)*
}

\author{
PAOLO RASPADORI \\ Department of Humanities, Università degli Studi di Perugia \\ Piazza Morlacchi, II, o6I23 Perugia, Italy \\ E-mail: paolo.raspadori@unipg.it
}

\begin{abstract}
AвSTRACT: Working conditions and labour unrest among service employees in the hotel and restaurant sector have, for a long time, have not been at the centre of attention of labour historians, especially in Italy. However, from the late nineteenth century a considerable number of cooks and waiters in Italian cities began to organize in order to improve their working conditions and to create alternative, cost-free forms of employment. From the early twentieth century, the trade unions of the employees of hotels and restaurants (grouped together in a National Federation in 1907) attempted to achieve these goals by means of strikes and demonstrations, some of them remarkably militant. Using a broad range of primary sources and quantitative data, this paper will first describe the characteristics of the working conditions of workers in hotels and restaurants in Italy; second, it will analyse the evolution of organizations, demands, and strike action by these staff from the beginning of the twentieth century to the advent of fascism. Distinguishing two waves of mobilization (1902-1907/1908 and 1919-1920), this paper aims, firstly, to highlight the similarities and differences between union actions by hotel and restaurant employees, on the one hand, and those of other workers on the other. Secondly, it focuses on the ways that the strikes induced serving staff to feel like "real" workers in terms of the outlook and behaviour of industrial workers.
\end{abstract}

Scholars who specialize in the labour movement and working-class history in Italy have yet to study in depth the situation of staff assigned to manual jobs in the tertiary sector. There are several reasons for this: the difficulty in finding sources, especially archival ones; the "productivist bias" (i.e. the belief of many scholars that only industrial workers can be considered

* This article is the revised and extended version of a paper presented at the annual Conference of the Association for the Study of Modern Italy, “'Basta!' Patterns of Protest in Modern Italy: History, Agents and Representations", organized by the University of London and the Institute of Germanic and Romance Studies and held in London on 23 and 24 November 20 I 2. The author wishes to thank an anonymous referee, the Editorial Committee, and David Mayer for their suggestions which helped to improve this article considerably. 
workers for all intents and purposes because they make use of and transform raw materials and semi-finished products); ${ }^{\mathrm{I}}$ and the relatively low weight of the service industry in the Italian economy until the mid-twentieth century. ${ }^{2}$ Consequently, few historians have been interested in the main features of this sector from the perspective of the labour market, the organization of work, or the activity of trade unions. $^{3}$

The study of hotel, restaurant, and bar workers has suffered a special lack of historiographic attention in Italy, a fact that contrasts markedly with other countries, particularly the United States, where the history of waiters, but also cooks and porters, has been examined from various perspectives. In a pioneering article in 1983, Mary Lee Spence retraced the working conditions of waiters in restaurants, cafeterias, trains, and boats in the west of the United States from the second half of the nineteenth century to World War I, focusing on the evolution of the labour market and the systems of payment. ${ }^{4}$ Dorothy Sue Cobble focused her attention on the history of American waitresses and their union organizations during the twentieth century, while Kerry Segrave analysed the economic and cultural function of tips in American society in the nineteenth and twentieth centuries and their impact on the staff of hotels, restaurants, and bars. ${ }^{5}$ Over the last twenty years, European scholars have followed these examples from North America and begun to study this group of service staff, extending the examination to cooks, to single but remarkable episodes of conflict, to the mode of operation of employment agencies, and to the ways in which the job of waiters was perceived and judged in

I. For an early Italian critique of the "productivist bias", see Aris Accornero and Nino Magna, "Il lavoro dopo la classe", Stato e Mercato, 17 (I986), pp. 253-270.

2. Vera Zamagni, "Il settore terziario nel processo di industrializzazione: l'esperienza italiana tra il i88 i e la II guerra mondiale”, in Luigi Frey, Renata Livraghi, and Vera Zamagni, Domanda e offerta di lavoro in attività terziarie (Milan, 1975), pp. I43-175.

3. Important contributions, however, have been published since the I990s. See, for instance, Raffaella Sarti, "Il servizio domestico: un canale di mobilità sociale? Il caso di Bologna (fine '700inizio '900)" in Società italiana di Demografia Storica, Disuguaglianze, stratificazione e mobilità sociale nelle popolazioni italiane (dal secolo XIV agli inizi del secolo XX), 2 vols (Bologna, 1997), I, pp. I45-167; Antonio Famiglietti, Le origini dell'attività sindacale nel settore dei servizi (I880-I925) (Rome, 2005); Silvia Salvatici, "'L'arte di offrire la merce con faccia sorridente e buon garbo'. Le commesse nell'Italia degli anni Venti e Trenta", in Chiara Giorgi, Guido Melis, and Angelo Varni (eds), L'altra metà dell'impiego. La storia delle donne nell'amministrazione (Bologna, 2005), pp. 99-I I8.

4. Mary Lee Spence, "They Also Serve Who Wait”, The Western Historical Quarterly, I 4 (1983), pp. $4^{-28}$.

5. Dorothy Sue Cobble, Dishing It Out: Waitresses and Their Unions in the Twentieth Century (Urbana, IL [etc.], 1991); Kerry Segrave, Tipping: An American Social History of Gratuities (Jefferson, NC [etc.], I998). 
literature or public opinion. ${ }^{6}$ In Italy, relatively little research has been done in this field; studies realized so far were less concerned with the aforementioned topics and focused more on the waiters as a social group (the organization of their work, the practices of their recruitment, their union activity), the service staff on transatlantic steamships, and the emergence of vocational education in the tourism industry. ${ }^{7}$

Nevertheless, none of the above mentioned studies have paid much attention to the labour unrest among hotel and restaurant workers as a whole. In Italy, above all, the specific characteristics that distinguish work in hotels and restaurants from other trades have only been superficially analysed. Furthermore, no interest has been shown in verifying the existence of a link between the nature of the job and the capacity not only of waiters, but also of cooks and other workers, to obtain better working conditions and better wages through strikes. Thus, the purpose of this article is first, to illustrate the distinctive traits of the trades in the Italian hotel and restaurant sector during the first few decades of the twentieth century, and to explain how these traits have influenced the labour movement and the type of relationship that it established with business associations. Second, the article intends to describe how and when labour conflicts involving hotel and restaurant employees have enabled them to act like "real" workers, i.e. similar to industrial workers rather than other groups of labourers such as servants, the self-employed, casual workers, etc.

Waiters, bar staff, and porters have indeed often been considered as servants, mini-entrepreneurs, and other types of non-standardized labourers. Their seasonal work, their constant contact with the lifestyle of the middle classes and the aristocracy, and their complaisance with

6. See, for example, John K. Walton and Jenny Smith, "The Rhetoric of Community and the Business of Pleasure: the San Sebastián Waiters' Strike of 1920", International Review of Social History, 39 (1994), pp. I-3 I; Alain Drouard, "Escoffier, Bocuse et (surtout) les autres...”: Towards a History of Cooks in France in the Nineteenth and Twentieth Century", in Marc Jacobs and Peter Scholliers (eds), Eating Out in Europe: Picnics, Gourmet Dining and Snacks Since the Late Eighteenth Century (Oxford, 2003), pp. 2 I 5-228; Peter Scholliers, "Anonymous Cooks and Waiters: Labour Markets and Professional Status of Restaurant, Café and Hotel Personnel in Brussels, I 840s-1900s", Food \& History, 2 (2004), pp. I37-165; Dieter Kramer, "Trinkgeld, Würde und Interessen. Eine Diskussion um das Bild des Kellners vor i 20 Jahren”, in Konrad Köstlin, Andrea Leonardi, and Paul Rösch (eds), Cameriere e cameriera. Una storia culturale (Cinisello Balsamo, 20I I), pp. 403-42 I.

7. Patrizia Battilani, "L'organizzazione del lavoro nel settore ricreativo. Il caso dei camerieri e delle imprese alberghiere fra Ottocento e Novecento", in Köstlin, Leonardi and Rösch, Cameriere e cameriera, pp. 197-213; Paolo Raspadori, "Lavorar servendo. Occupazione, condizioni di impiego e attività sindacale dei camerieri italiani tra gli anni ottanta dell'Ottocento e la prima guerra mondiale", in ibid., pp. 2 17-239; Andrea Zanini, "Formazione professionale e sviluppo: gli esordi dell'istruzione alberghiera in Italia", Società e storia, 35 (20I 2), pp. 355-386; idem, "Grand Hotel Rex. I servizi alberghieri e il personale di bordo sui transatlantici italiani”, in Paolo Piccione (ed.), Transatlantico Rex. Il mito e la memoria (Cinisello Balsamo, 2013), pp. 203-2 I 3. 
customers (due to the expectation of gratuities, the predominant pay in the profession $)^{8}$ have made them the object of suspicion and sometimes scorn on the part of working-class representatives. ${ }^{9}$ From the beginning of the twentieth century, hotel and restaurant managers as well as journalists have regarded subordinate occupations in the hospitality sector as the early stages of a career that could lead to becoming an owner or taking a managerial role if workers demonstrated dedication and sacrifice in performing their duties. Workers and entrepreneurs were considered part of a single community that shared the same interests. Waiters and cooks were thought to receive better wages and conditions compared to factory workers and peasants; this belief was based, to a high degree, on some biographies of maitres and chefs of luxury hotels and restaurants. ${ }^{10}$

Over time, this judgement consolidated itself in public opinion, among hotel and restaurant owners, among members of the trade unions of other sectors, and among scholars of the history of the working class. All of these groups have considered waiters and cooks as being more similar to professional men than to employees, not deserving to be thought of as part of the labour movement and not worthy of corresponding historiographical analysis. Above all, they were considered unable or unavailable to rebel against their bosses, the mere possibility of protests by this group to obtain a rise in wages or a reduction in working hours thus becoming almost inconceivable.

Nonetheless, influenced by socialism at the end of the nineteenth century, groups of hotel and restaurant employees formed unioni di miglioramento (improvement associations) and leghe di resistenza (resistance leagues), revealing the degrading conditions of work, the uncertainty of employment and payment, the long working hours, and the control of employment left to the intermediation of private actors, who often took advantage and extorted money from workers looking for an engagement. These associations called on employees to organize themselves and to protest against their employers in order to enhance their conditions. ${ }^{\text {II }}$

8. On gratuities as a main source of income for waiters and waitresses in Europe before World War I, see Patricia Van den Eeckhout's article, "Waiters, Waitresses, and their Tips in Western Europe before World War I" in this issue of the International Review of Social History, pp. 349-378. 9. Raspadori, "Lavorar servendo", p. 2 I 8.

I0. For some typical examples of how this image of hotel and restaurant staff was rendered, see "Gli scioperi e la Cassa di M.S. fra gli impiegati d'albergo", Rivista degli alberghi, г May г90 I, p. 2; "Ufficio gratuito di collocamento per impiegati d'Albergo", ibid., i6 October 1902, p. I; Alfredo Campione, "Sulla Inchiesta dell’Ufficio del Lavoro", ibid., 8 March i915, p. I; "Lo sciopero dei camerieri a Roma", Corriere della Sera, 6 June I9 19, p. 2; "Lo sciopero dei camerieri”, ibid., I6 June I920, p. 3; "I lavoratori della mensa", Il Resto del Carlino, 22 May I920, p. 2.

I I. See, for instance, the following: E. Caucci, "Appello ai camerieri”, Il Cameriere, is February I902, p. 2; S. Alfieri, "I nostri Comizi", Il Lavoratore della mensa, is April I903, p. 3. See also Raspadori, "Lavorar servendo", pp. 229-234. 
These activities indeed came together with the first strikes by hotel and restaurant staff from 1902 onwards.

This article addresses the labour unrest of Italian hotel and restaurant staff from its beginnings, at the outset of the last century, to its temporary end, which can be set in 1923 as a consequence of the assaults of the fascist action squads and of employers' reaction to the unrest of the so-called biennio rosso (two red years, I919-1920). Additionally, this article aspires to answer two questions: what role did the actions of waiters, cooks, porters, and other staff play in influencing their behaviour and selfidentification as a group? Were they indicative of a change towards approaches and styles in organization and contentiousness similar to those prototypically demonstrated by industrial workers?

Sources used for the research presented here include statistical data about strikes and emigration, population censuses, the Bollettino dell'Ufficio del lavoro (organ of the Statistical General Direction of the Ministry of Agriculture, Industry and Trade), issues of national newspapers (Il Corriere della Sera, La Nazione, Il Resto del Carlino, Il Secolo XIX) and of the main union and employers' magazines in the field (Il Patto, Il Cameriere, Il Lavoratore della mensa, Il Lavoratore d'albergo e della mensa, Rivista degli alberghi), and public security documentation concerning unrest among restaurant and hotel employees, which is preserved in the Archivio Centrale dello Stato (National State Archive). In particular, the official data about strikes will be used as a starting point to develop an overall analysis of the historical evolution of the protests of these workers and to highlight some general features of the two strike waves that marked the period studied here (1902/1907-1908 and 1919-1920). While there are several limitations to these sources (to be specified at the beginning of the second section), such a quantitative approach to the study of conflicts allows us to consider waiters, cooks, and porters as an aggregate group and to study their contentiousness collectively, thus permitting comparisons with the conflicts of workers from other sectors. Meanwhile, the peculiarities of this group and the different ways they conceived union and strike action will be reconstructed, making use of trade-union journals and archival documents.

The article is divided into three sections. The first section outlines the evolution of the hotel and restaurant workforce and its unionization from the beginning of the twentieth century until 1923, and points to the occupational characteristics in this sector that affected both the way that employees' associations functioned and their ability to put forward their demands. The second section describes the quantitative trend of strikes, analysing their main characteristics, the way they were conducted, and their outcomes. The third section summarizes the results of the analyses of the previous sections and offers some concise assessments of the conflicts promoted by serving staff. 


\section{THE HOTEL AND RESTAURANT WORKFORCE IN ITALY AND ITS UNION}

The first census of hotels was formed by the Ente Nazionale per l'Industria Turistica (National Agency for the Tourism Industry) between I 923 and I925, whereas the first census of the whole trade (which also included other establishments, such as restaurants, bars, and cafés) occurred only in $1927 .{ }^{12} \mathrm{To}$ evaluate, albeit approximately, the level of employment in the hotel and restaurant sector before 1925 , an analysis of population censuses, which were conducted regularly every ten years from I90I, is required. It is important to consider that such records have many limitations. They underestimate both child and female labour (especially when the latter were involved in nonstandardized labour relations); they do not distinguish between employed and unemployed workers, and they are subject to continuous changes in the classification of professions and in territorial extension. These factors make comparison among data over the course of time difficult. ${ }^{{ }^{3}}$

After consideration of the flaws in the source material and the number of employed workers on the basis of the sufficiently accurate census of 1936 (which, contrary to earlier censuses, allows us to distinguish cooks, waiters, porters, etc. from workers in other service sectors), the number of employees at national level from I90I to 1923 was estimated by interpolating data from the censuses of I9I I, I92I, and I93 I. Data concerning members of the Federazione Italiana dei Lavoratori di Albergo e Mensa (FILAM), (the National Union of Hotel and Catering Employees founded in 1907 and whose figures about members are available until 1922) were also used. ${ }^{\mathrm{I}}$ This union was influenced by socialism and affiliated with the Confederazione Generale del Lavoro, (CGdL), which was founded in 1906.

Caution is advised when considering the data contained in Table I, but some observations can be made. Over the first decade of the twentieth century, the number of hotel, restaurant, and bar employees was increasing, reaching a little more than 90,000 in I9II. From I9I 2 to I 92 I, in contrast, the number of these workers decreased considerably to less than 60,000 , likely due to the negative effects of World War I on tourism and consumption. The number began to increase again in the following 2 years. Furthermore, these professions underwent a partial feminization over this 20 -year period. The percentage of women in the total manpower increased from I 5.33 in I90I to 21.83 in I $92 \mathrm{I}$. The unionization rate showed a trend that was opposite to that of employment.

I 2. Nicola Muzzarelli, "Il turismo in Italia tra le due guerre", Turistica, 6 (I997), pp. 46-78, 65.

I3. Ornello Vitali, Aspetti dello sviluppo economico italiano alla luce della ricostruzione della popolazione attiva (Rome, 1970), pp. 2-I 5; Vera Zamagni, "A Century of Change: Trends in the Composition of the Italian Labour Force, I88I-198I”, Historical Social Research, 44 (1987), pp. $36-97$.

14. Famiglietti, Le origini dell'attività sindacale nel settore dei servizi, pp. 98-100. 
Table I. Hotel and restaurant male and female workers in Italy from I $90 \mathrm{I}$ to 1923 and members of FILAM from 1907 to 1922.

\begin{tabular}{lcccc}
\hline Years & $\begin{array}{c}\text { Male } \\
\text { workers }\end{array}$ & $\begin{array}{c}\text { Female } \\
\text { workers }\end{array}$ & $\begin{array}{c}\text { Enrolled } \\
\text { FILAM }\end{array}$ & $\begin{array}{c}\text { Rate of unionization } \\
\text { (percentage) }\end{array}$ \\
\hline 1901 & 74,235 & 13,443 & - & - \\
1902 & 74,215 & 13,861 & - & - \\
1903 & 74,196 & 14,279 & - & - \\
1904 & 74,176 & 14,697 & - & - \\
1905 & 74,157 & 15,115 & - & - \\
1906 & 74,137 & 15,533 & - & - \\
1907 & 74,118 & 15,951 & - & 5.58 \\
1908 & 74,098 & 16,369 & 5,052 & 4.86 \\
1909 & 74,079 & 16,787 & 4,419 & 2.86 \\
1910 & 74,059 & 17,205 & 2,614 & 2.51 \\
1911 & 74,040 & 17,623 & 2,298 & 3.96 \\
1912 & 71,338 & 17,056 & 3,499 & 4.21 \\
1913 & 68,637 & 16,489 & 3,588 & 2.03 \\
1914 & 65,936 & 15,922 & 1,665 & 1.18 \\
1915 & 63,235 & 15,355 & 928 & 0.67 \\
1916 & 60,534 & 14,789 & 505 & 0.90 \\
1917 & 57,832 & 14,222 & 650 & 1.11 \\
1918 & 55,131 & 13,655 & 765 & 13.46 \\
1919 & 52,430 & 13,088 & 8,821 & 19.28 \\
1920 & 49,729 & 12,521 & 12,000 & 16.95 \\
1921 & 47,028 & 11,955 & 10,000 & 2.0 \\
1922 & 50,064 & 13,392 & 1,267 & - \\
1923 & 53,100 & 14,830 & - & - \\
\hline
\end{tabular}

Source: Calculations based on: Italian population censuses (I90I-I93 I); Ministero dell'Agricoltura, Industria e Commercio (MAIC), Statistica delle organizzazioni italiane dei lavoratori (Rome, I908-I918); "Un anno di vita sezionale. Relazione morale e finanziaria”, Il Lavoratore d'albergo e della mensa, i February i924, p. 4; Luciana Marchetti (ed.), La Confederazione Generale del Lavoro negli atti, nei documenti, nei congressi I906-1926 (Milan, I962), pp. 42 I-422.

Note: The numbers of male and female workers for the years I90I, I9I I, and I92 I were obtained directly from the data of the censuses, whereas the numbers in the remaining years are an estimate obtained through linear interpolation of census data.

In comparison with unionization in 1908 , the rate decreased or was stagnant until the end of World War I and began to rise substantially during the "two red years" and until the advent of fascism.

The uneven occupation trend and the slow but uninterrupted rise in female presence during the first twenty-five years of the last century are consistent with what was registered in the service sector as a whole in the same period. ${ }^{\text {Is }}$ dall'Unità a oggi (Venice, 2002), pp. 34 and $45-46$. 
Furthermore, the difficulties the union movement encountered when it attempted to spread among employees was in tune with the overall history of Italian industrial and agrarian unionism during that period. ${ }^{16}$ However, the peculiar constitution of the labour market in the hotel and restaurant industry set the first hotel and restaurant workers' organizations apart from other sectors of the labour movement and led, at least until the end of World War I, to a rather precarious existence both on a local and a national level, and a noticeable weakness of the FILAM in defending the interests of their constituency and in pushing their demands.

From the end of the nineteenth century to World War I, this sector's labour market was characterized by extremely varied conditions of employment and wages. The workforce was divided into two fundamental categories by the actors of the time: internal and external workers. The former, which did not have direct contact with customers, included staff working in the kitchens and handling the cellars of taverns as well as workers in restaurants, bars, and cafés, cloakroom attendants, and washerwomen. Their pay consisted of a fixed wage and the possibility of receiving room and board in the workplace if they were hotel employees, or receiving board only in the case of restaurant, café, or bar employees. Workplaces were often unhealthy, especially in the case of kitchens and laundries, due to excessive heat, humidity, and poor ventilation, and the working hours could reach 16 hours a day. Although the pay of a cook could be very high (approximately 200 lire a month in I9I4 in Milan), compared to other employees and manual workers in the industry and in the tertiary sector, the pay of a cellarman or a scullery boy (that is, those dealing with the carriage of wine and food from the storehouse to the place of consumption, and with dishes and laundry) barely exceeded I lire a day. The average wage of a cook's assistant in Milan in I90 I did not reach I.8 5 lire a day or 100 a month in I9I $3 .{ }^{17}$ Employees with less-skilled positions were also less educated, often illiterate, and frequently came from the countryside or from small villages in more remote areas. ${ }^{\mathrm{I}} 8$

I6. Idomeneo Barbadoro, "Lo sviluppo del movimento sindacale in Italia: forme di contrattazione e di rappresentanza (1900-1920)", in Maurizio Antonioli et al., Sindacato e classe operaia nell'età della seconda internazionale (Florence, 1983), pp. 29-74; Musso, Storia del lavoro in Italia, pp. I I $2-152$.

17. For a comparison with industrial workers, consider that the average daily wage of an Italian factory worker in I90I was I.86 lire, whereas the average monthly wage was 73.84 lire in I9I3; Vera Zamagni, "Salari e profitti nell'industria italiana tra decollo industriale e anni ' 30 ", in Sergio Zaninelli and Mario Taccolini (eds), Il lavoro come fattore produttivo e come risorsa nella storia economica italiana (Milan, 2002), pp. 243-254, 25 I, Table I.

I8. "L’organizzazione del personale interno", Il Patto, I August i894, p. 2; "Le condizioni del personale interno", Il Cameriere, is March I90 I, p. I; Luigi Gallazzi, "Del personale di cucina”, ibid., Is April ı90 I, p. 2; Alberto Altieri, "Per gli addetti alle cantine", ibid., is July I90 I, p. 2; A. Derbasi, "Il personale interno di caffè e ristorante", ibid., Is October I90 I, p. 2; Mazzoni, 
External staff included employees who directly served customers, such as waiters, barmen, concierges, elevator operators, porters, and governesses. Until the end of the i 880 s, they were paid a fixed wage and, in some cases, could also receive a percentage of the takings. Subsequently, owners increasingly left it to these employees to maintain themselves through gratuities instead of giving them pay. This habit became established, although with great regional variations: waiters and porters in some areas relied on gratuities only; in others, they also received a type of basic pay that was very low; and in yet other areas, gratuities were collected by the chief waiter or deposited by customers in a box (the so-called tronc) and then assigned by the owner to waiters after retaining a certain percentage of the total amount. ${ }^{19}$ In some luxury hotels and restaurants, the employees may even have paid the owner for the privilege of working in a place where there was the possibility of receiving considerable gratuities. ${ }^{20}$ The habit of using gratuities as pay for external staff, a general trend at the end of the nineteenth century, is attributed in the scholarly discussion to the significant growth in the numbers of tourists and travellers lodging in hotels and boarding houses, as well as to the growing ranks of those who frequented restaurants and bars to consume a meal while travelling for work or leisure.

This growth was, of course, a consequence of general economic and industrial development (which in Italy had only started in the mid-I88os) and, in particular, to the spread of trains and boats as mass means of transportation. It produced an expansion of the middle classes and their out-of-household expenses as well as some boost to the hitherto aristocratic custom of travelling for leisure. The increase in customers made it more convenient for restaurant and hotel managers to resort to the good will of customers to pay their staff instead of keeping wages stable or increasing them. ${ }^{2 \mathrm{I}}$ Moreover, gratuities proved to be an excellent incentive to stimulate employees to work more hours and to pay better attention to customers. Additionally, waiters, doormen, and porters availed themselves of both room and board in hotels, and of board only in bars and restaurants.

Work hours could reach seventeen or eighteen a day, though not continuously. Waiters had to pay their assistants. Serving staff were also subject to a deduction from tips by the employer as prior security for the possible

\footnotetext{
"Vecchio tema", Il Lavoratore d'albergo e della mensa, is July i913, p. i; Frigio, "I sacerdoti del formello!!”, ibid., 24 January i9i 5 , p. I.

19. For a comparative survey of the role of gratuities in the hospitality sector in several European countries see Van den Eeckhout, "Waiters, Waitresses, and their Tips".

20. G.C., "Fin dove arriverà lo sfruttamento del cameriere?”, Il Patto, I May I893, p. 2; Alberto Altieri, “La tassa sulle Mancie”, Il Cameriere, is April I90 I, p. 2.

2 I. Segrave, Tipping, pp. 5 and I4; Patrizia Battilani, Vacanze di pochi, vacanze di tutti. L'evoluzione del turismo europeo (Bologna, 2009), pp. 23-32 and 234-239; Annunziata Berrino, Storia del turismo in Italia (Bologna, 201 I), pp. I47-1 59.
} 
breakages of plates or stealing of silverware, and they had to pay for their own clothes and work tools (e.g. toothpicks, notebooks for orders). ${ }^{22}$ Thus, the incomes of this profession were extremely varied and differentiated. In I 893 in Genoa, a waiter would typically earn a single lire a day. Eight years later in Milan, a waiter working downtown who received 7 lire through gratuities could only keep 3 after deductions and taxes had been applied. In I9I 3 in Milan, waiters' assistants collected from 20 to 50 lire a month, whereas the income of hotel waitresses did not exceed 40 lire. ${ }^{23}$

Similarly to what occurred in France, Belgium, and the United States during the same period, ${ }^{24}$ given the absence of formal education for professions in the hospitality sector and the predominance of on-the-job training, both internal and external staff suffered the consequences of labour oversupply. Only skilled occupations, such as those of chefs, maitres d'botel, clerks, and cashiers, were sheltered from unemployment. Other employees, especially waiters, could easily lose their jobs and be replaced by a heterogeneous mass of unskilled workers migrating from the countryside and willing to work for very low wages, or students, former members of the army, vagabonds, or even decayed aristocrats. ${ }^{25}$ Such a situation had two important effects: marked geographical mobility and company turnover as well as the importance of experience for the entire class of employees.

On the one hand, anyone who wanted to find a job was often compelled to move following the rhythm of the seasons: during winter in the resorts of the Tyrrhenian or Adriatic Sea, during spring in the cities of art (Rome, Florence, Venice, Naples), during summer in the mountains. ${ }^{26}$ In addition to roaming around the Italian peninsula, many workers migrated abroad to learn one or more foreign languages and returned to

22. Emilio Prandoni, "Svegliatevi", Il Patto, is November i 894, p. 2; "Le Condizioni dei Camerieri di Albergo", Il Cameriere, is February ı 90 I, p. I; Caucci, “Appello ai camerieri”, p. 2. 23. Data collected from Gaetano Traxino, "Infamie capitalistiche", Il Patto, i June i893, p. I; Altieri, "La tassa sulle Mancie”, p. 2; Nicola, "Un'assalto [sic] degli albergatori”, Il Lavoratore d'albergo e della mensa, is July i9i 3 , pp. 2-3.

24. Spence, "They Also Serve Who Wait”, pp. I 5-16; Drouard, “Escoffier, Bocuse et (surtout) les autres...”, p. 22 I; Scholliers, "Anonymous Cooks and Waiters”, pp. I38-14I.

25. A.P., "Vediamo le cause”, Il Patto, I July I 893, p. 2; L[uigi] G[allazzi], "Astenetevi dal recarvi a Milano in cerca di lavoro”, Il Lavoratore della mensa, is February i904, p. 2; Luigi Gallazzi and Pietro Premoli, "La disoccupazione tra i lavoratori della mensa", Il Lavoratore d'albergo e della mensa, I January 1907, p. 3; E.B., "Sulle condizioni della nostra professione in Italia", Rivista degli alberghi, I7 October 1908, p. 2; "Per l'istituzione di una Scuola professionale in Italia", ibid., 25 November I91 2, p. 3.

26. "La disoccupazione”, Il Patto, is November I 894, p. 3; Caucci, “Appello ai camerieri”, p. 2; Luigi Gallazzi, "Statistica. Cifre impressionanti”, Il Lavoratore della mensa, 23 September 1904, p. 3. Before World War I, the flow of tourism increased during the winter and decreased during the summer in the Mediterranean seaside resorts; see Battilani, Vacanze di pochi, vacanze di tutti, pp. I I $2-$ I I 8 . 
find a new job at home; otherwise, they settled permanently in another country. Considering only delivery boys, porters, and waiters (the only categories of the sector for which data concerning emigration are available before I92I), in 1904, 3,739 of them emigrated from Italy; in I909, this number had risen to $6,07 \mathrm{I}$, and in $19 \mathrm{I} 3$, it had risen to $10,45 \mathrm{I} .{ }^{27}$ It is probable that many of those workers returned periodically to Italy after some years of training abroad. In I 90 I, for example, more than 4,000 Italian hotel and restaurant employees lived in London, concentrated in Soho; however, only 30 per cent of them resided there permanently. The remainder returned to Italy as soon as they had acquired sufficient knowledge of English. ${ }^{28}$

In contrast, lacking an employment service run by the state, private mediators and agencies that charged fees were the only means of obtaining a job for those who had no personal contacts. The mediators were often former entrepreneurs or former workers who headed small agencies, often in an inn or a tavern, making use of their professional experience and their network of contacts. Unlike the industrial sector, where large- and medium-sized companies hired workers directly, employment agencies were very common in the hospitality sector and functioned efficiently. For this reason, most employees turned to them to find jobs rapidly, while the agencies would ask one-third to one-half of the worker's first wage as a fee for the mediation. ${ }^{29} \mathrm{~A}$ few friendly societies of hotel and restaurant workers (which had chiefly arisen in northern-central Italy from the middle of the nineteenth century) opened employment offices for their members to compete with private mediators. In any case, the friendly societies also required the payment of fees for this service, although they were lower than those of private agencies. In October I90I, the Società Italiana degli Albergatori (SIA, Italian Association of Hotel Owners) opened an employment office without fees at its headquarters in Genoa. Anyone who wanted to benefit from this service was required to pay a lire una tantum as a membership fee. However, after two years, employers complained about the poor outcomes because few members of the association actually used it

27. Data from Ministero di Agricoltura, Industria e Commercio [hereafter, MAIC], Direzione Generale della Statistica [hereafter, DGS], Statistica della emigrazione italiana per l'estero (Rome, ad annum). It should be noted that this source only offered numbers on workers leaving Italy. It did not take return migration into account, nor did it reveal how many of these migrants were seasonal or temporary.

28. Ministero degli Affari esteri, Commissariato dell'emigrazione, Emigrazione e colonie. Raccolta di rapporti dei rr. agenti diplomatici e consolari, I, Europa, Parte 2a, Svizzera - Austria Ungheria - Gran Bretagna - Spagna e Gibilterra - Portogallo - Malta (Rome, I903), pp. I 50-I 5 I and 163 .

29. "Il collocamento gratuito", Il Lavoratore della mensa, i 8 March I905, p. I; Ministero per l'industria, il commercio e il lavoro, Ufficio del lavoro, Inchiesta sulle condizioni dei lavoratori d'albergo e mensa (Rome, I919), pp. I6-17. 
to find the employees they needed or they made their requests to the office too close to the high season to be satisfied. ${ }^{30}$

Faced with this situation, workers experienced several difficulties in building solid organizations to defend their interests and, once they had been established, discovered how difficult it was to achieve overall improvement for the trade. Friendly societies whose aim was to provide economic and health assistance to their members in case of need were founded and managed with the support of employers, ${ }^{3 \mathrm{I}}$ and in the I890s, circoli di fratellanza (brotherhood clubs), unioni di miglioramento and leghe di resistenza were formed, again in the central and northern areas of the peninsula. The purpose of these associations was to improve workers' standard of living and conditions of employment, which was to be achieved by propaganda, education, and acts of protest against the entrepreneurs. The fundamental demands of the movement were expressed in meetings and rallies, as well as through petitions and complaints to the employers: the abolition of private employment agencies and of the corresponding fees for employment to be replaced by free-of-charge municipal or labour movement controlled offices; a weekly day of rest; the abolition of charges and other deductions from tips; a minimum wage; and the reduction of working hours.

A first attempt to coordinate this heterogeneous organizational structure was made in November I 892 with the creation of the Federazione Italiana delle Associazioni fra Cuochi, Camerieri, Caffettieri, Pasticcieri, Cantinieri e Personale di Bordo (Italian Federation of Cooks, Waiters, Barmen, Confectioners, Cellarmen, and Ship's Crew), whose Central Committee was located in Florence. The Federazione was short lived, breaking up after two years because it mainly consisted of friendly societies that were not inclined to enter into conflict with employers (of the twenty-three associations that had joined, only six were other types of organizations, such as

30. On the role of private mediators and employment agencies, see "Il passato e l'avvenire", $I l$ Patto, I February I 894, p. 2; "I mediatori e le agenzie di collocamento", ibid., I July i 894, pp. 2-3; Luigi Gallazzi, "Lotta di classe", Il Cameriere, is February I902, p. 2; "Chi pensa a noi?”, Il Lavoratore d'albergo, I May I906, p. 2; "Ufficio gratuito di collocamento pel personale d'Albergo", Rivista degli alberghi, I September ı90 I, p. I; "Lagnanze sul nostro Ufficio di collocamento", ibid., I September I903, p. I. On employment mediation and job placement in Italy from the end of the nineteenth century to World War I in general, see Stefano Musso, Le regole e l'elusione. Il governo del mercato del lavoro nell'industrializzazione italiana (I 888-2003) (Turin, 2004), pp. 23-70.

31. In January I 885 in Italy, there were 34 friendly societies of hotel, inn, tavern, and café staff active, with a total of 4,558 members; ro years later the number had increased to 37 , and the number of members had risen to 5, I I 8. See Raspadori, "Lavorar servendo", p. 232. On the history of Italian friendly societies from the mid-nineteenth century to World War I, see Lia Gheza Fabbri, "Le società di mutuo soccorso italiane nel contesto europeo fra XIX e XX secolo", in Vera Zamagni (ed.), Povertà e innovazioni istituzionali in Italia. Dal Medioevo ad oggi (Bologna, 2000), pp. 503-528. 
resistance leagues or brotherhood clubs), and due to financial difficulties (less than half of the associations paid the fee), as well as rivalries between the Milan and Florence leagues. ${ }^{32}$ A new effort to create a national union was launched in October 1902 when, in the wake of the success achieved in the first great strikes of the cooks and waiters of Milan and Florence (which I will focus on in the next section), the Federazione Nazionale fra $\mathrm{i}$ Lavoratori della Mensa (National Federation of Catering Workers), whose Central Committee was located in Milan, was established. Despite the favourable circumstances, the lack of funds, inability to increase membership substantially (at the end of 1903 , there were only I,6 I 2 members scattered over I 6 cities) and, also in this case, local rivalries led to the dissolution of the organization within a year. Subsequently, the labour movement tended to join the Camere del lavoro (Houses of Labour) of each town while waiting for the strengthening of its ranks that would make it possible to try once again to build a proper federal structure. Nevertheless, in October 1906, only eight hotel and restaurant workers' organizations existed: the Unioni and Leghe of Milan, Genoa, Turin, Pavia, Padua, Parma, Bologna, and Rome. ${ }^{33}$

The following year, the FILAM was founded in Rome. Twenty-four workers' associations in seventeen cities joined, but it suffered from various deficiencies that made its attempts to elaborate a coherent programme and a set of demands rather difficult. Its first secretary, in charge until i 9 I I, was a socialist lawyer, Giovani Pozzi, which indicates that this was an organization still a long way from being self-governed by the workers themselves. Due to the decision made at the founding meeting of FILAM to include friendly societies in the union as well, there were several disagreements on the strategies to be adopted (dialogue or conflict with the employers) as well as the organizational model (based on distinctions of trade or categories as against structured in local sections or regional committees). The perpetual rivalries between Milan, Florence, and Rome for the seat of the organization functioned as an additional drag. ${ }^{34}$ Most importantly, however, the enduring divisions within the organization of work weakened union activism, created cleavages among workers, and prevented the creation of stable associations. This was exacerbated by the cultural

32. Famiglietti, Le origini dell'attività sindacale nel settore dei servizi, pp. 74-84.

33. Ibid., pp. 90-97; Gallazzi and Premoli, "La disoccupazione tra i lavoratori della mensa", p. 3. The Camere del Lavoro, established in I89I, were local institutions, mostly in medium and large cities, which brought the unions and other organizations of various trades in agriculture, industry, and services together. On this subject, see Musso, Storia del lavoro in Italia, pp. I I 8-I I9.

34. Famiglietti, Le origini dell'attività sindacale nel settore dei servizi, pp. Io I-I I9. On Pozzi, see Francesco Bogliari, "Pozzi Giovanni”, in Franco Andreucci and Tommaso Detti (eds), Il movimento operaio italiano. Dizionario biografico. I853-1943, IV (Rome, 1978), pp. 209-2 Io. 
stereotypes about the trade (mentioned above), which were fuelled by employers and by the rest of the labour movement and influenced the mentality of employees.

At the same time, these notions of cultural differences among the workers of the sector were actively cultivated by many of these workers themselves: the differences in payment between internal and external staff - fixed wages for the former, gratuities for the latter - created a substantial barrier. ${ }^{35}$ Tips incited waiters and porters to work harder and to be favourably disposed towards guests and bosses in the hope of increasing their incomes; additionally, the several breaks and periods of inactivity throughout their workday meant that they were not particularly keen on a reduction of service hours. In contrast, the fixed wages of internal staff with a working environment devoid of contact with customers and long working hours positioned them much closer to unskilled factory workers. From I 907 to I9I 3, the FILAM position on the abolition of tipping was alternating: first, it required that tips be replaced by fixed wages; then, that they be replaced by a tax on service payable to the waiters; and finally, that the incomes of all workers be increased in general terms. ${ }^{36}$

In any case, many waiters and doormen felt more like associates of employers or as though they were self-employed, rather than actual employees. They saw themselves as distinct from peasants and workers. Wearing an elegant suit similar to a uniform and bent on being flawless in appearance, they saw the incomes that could be gained by maitres or concierges. Knowing that some hotel owners and restaurant keepers had begun their careers as delivery boys or waiters' assistants, they often considered their positions as temporary or as a first step to opening their own businesses. ${ }^{37}$ These factors, as well as the excess of supply in the labour market, were discouraging when it came to improving their status as workers and joining strikes. ${ }^{38}$

35. For an acknowledgement of this barrier at the time see, for instance, Luigi Gallazzi, "Divisione", Il Cameriere, is April igo2, p. I.

36. Bollettino dell'Ufficio del lavoro, June 1909, p. i I20; Famiglietti, Le origini dell'attività sindacale nel settore dei servizi, pp. 98-102; Raspadori, "Lavorar servendo", p. 234.

37. Also in the case of saleswomen in department stores many felt that, despite their low wages, they belonged to a social class higher than that of factory workers: they nurtured some expectations for their careers, wore elegant dresses at work, and had continuous contact with a middleclass clientele. See Silvia Salvatici, "Al servizio dei consumatori. I lavoratori e le lavoratrici dei grandi magazzini”, in Stefano Cavazza and Emanuela Scarpellini (eds), Il secolo dei consumi. Dinamiche sociali nell'Europa del Novecento (Rome, 2006), pp. I I7-I 39, I $23-\mathrm{I} 24$.

38. Such self-images of staff are reflected, for instance, in "La legge sull'Ufficio del lavoro in rapporto agli albergatori e al personale d'albergo", Rivista degli alberghi, i September 1903, p. I; Giacinto Molinatti, "Ai Lavoratori della Mensa”, Il Lavoratore della mensa, is May 1903, p. I; F.B., "L'affinità", ibid., is March I904, p. I; Mariano Ianni, "Illusioni e realtà", Il Lavoratore d'albergo, i May 1906, p. I; "Una visita alla scuola professionale del TCI per gli addetti agli alberghi”, Rivista degli alberghi, 30 November 1914, p. 3 . 
Although these factors hampered the action of union activists, in 1902 there was a sudden, and relatively successful, explosion of conflict in this sector. This prepared the ground for a much stronger wave of unrest in 1907 and I908. Although this wave subsequently receded, strike action occurred every year in several cities of the peninsula. If such protests demonstrated that even waiters and cooks could "rebel" like other workers, the strikes were able to mobilize the majority of employees and unite a highly fragmented group of workers only under certain conditions.

\section{BRIEF OR HARSH, MODESTLY OR WELL-ATTENDED: \\ STRIKES IN THE HOTEL AND RESTAURANT SECTOR}

The data concerning the number of strikes, strikers, and lost working days in the hotel and catering sector are contained in the annual statistical series edited by the Ministero di agricoltura, industria e commercio (Ministry of Agriculture, Industry and Commerce). By analysing such data and comparing it with those of other sectors, it is possible to assess the state of relationships between employees and employers as well as the ability to mobilize the former by union organization. The reliability of this source, however, is limited. Several scholars have noted that these statistics do not consider political strikes and other expressions of worker protest and that the criteria underlying the survey are not accurate enough (for example, they do not distinguish the strikers by gender or age). ${ }^{39}$ Yet, despite such flaws, the statistics about strikes can help to explain the evolution of the conflicts of subordinate classes, including hotel and restaurant staff. It is necessary to add, however, that the statistical series on strikes include hotel, restaurants, bars, etc. in the wide category of "commercial businesses" (pubblici esercizi), which also includes other establishments such as barbers' shops, pastry shops, and bakeries. Yet, the source allows us to separate the information by sub-sectors and thus to reconstruct the trend of strikes only for hotel, restaurant, and café employees.

Table 2 overleaf shows that until the end of World War I in most years strikes were few (less than ten) and that, with the exception of the great unrests of Florence and Milan in May-June 1902 and Florence in 1908, the participation was low, usually less than roo strikers. It is not possible to identify from the source the number of lost working days in the sector between 1907 and I910, but, in general, it seems that the conflicts were very short. While the general strike of waiters, cooks, and delivery boys that took place in La Spezia in I9I I lasted approximately a month (resulting in a

39. See, for instance Roberto Franzosi, “Cent'anni di statistiche sugli scioperi. Una rassegna critica dei metodi e dei limiti della ricerca quantitativa sul conflitto industriale", in Gian Primo Cella and Marino Regini (eds), Il conflitto industriale in Italia. Stato della ricerca e ipotesi delle tendenze (Bologna, 1985 ), pp. $2 \mathrm{I}-54$. 
Table 2. Number of strikes, strikers, and lost working days in the hotel and catering sector in Italy from 1902 to 1923.

\begin{tabular}{lccc}
\hline Years & Strikes & Strikers & Lost working days \\
\hline 1902 & 5 & 7,513 & 21,143 \\
1903 & - & - & - \\
1904 & - & - & - \\
1905 & - & - & - \\
1906 & - & - & - \\
1907 & 5 & 394 & - \\
1908 & 13 & 1,092 & - \\
1909 & 2 & 24 & - \\
1910 & 4 & 295 & - \\
1911 & 7 & 179 & 2,148 \\
1912 & 2 & 34 & 64 \\
1913 & 3 & 20 & 100 \\
1914 & 1 & 37 & 74 \\
1915 & 3 & 80 & 88 \\
1916 & 2 & 176 & 1,063 \\
1917 & 3 & 747 & 1,674 \\
1918 & 2 & 153 & 451 \\
1919 & 2 & 19,274 & 153,100 \\
1920 & 20,728 & 590,534 \\
1921 & 51 & 7,356 & 73,327 \\
1922 & 29 & 108 & 700 \\
1923 & 6 & - & - \\
\hline
\end{tabular}

Source: Data on elaborations by MAIC, Direzione Generale della Statistica (DGS), Statistica degli scioperi avvenuti in Italia (Rome, ad annum).

Note: From I 903 to I 906 , strikes in the hotel and catering sector were not recorded. For the years 1907, 1908, I909, and I910, data about lost working days regarding the hotel and catering sector are unavailable.

relatively high number of lost working days in that year), most others ran out of steam within a week or less. Compared with the work stoppages that occurred in the same period in the construction industry, engineering and shipbuilding, or agriculture, those in the hotel and restaurant sectors were small. This type of labour conflict, characterized by a low number of participants, low frequency, and high cost for the workers in terms of lost wages and dismissals, has been described by sociologists and economists as "primitive/traditional" or "heroic". ${ }^{40}$ Such strikes were a consequence of an age in which the working classes were confronted with nonacknowledgement of their civil, social, and economic rights. Furthermore, the years 1902/1907-1908 and 1919-1920, which were the peaks of these

40. Giovanni Arrighi, “Labor Unrest in Italy, I880-1990”, Review, I8 (I995), pp. 5 I-68, 52. 
conflicts, coincided with the most turbulent periods in the industrial relations of pre-fascist Italy. ${ }^{4 \mathrm{I}}$

Taking into consideration the ratios between strikers and strikes (magnitude), lost working days and strikers (severity), and lost working days and strikes (duration), as shown in Table 3 overleaf, a similarity between the trend of average national values and the trend of the struggles of waiters and cooks is evident. Although the latter are well below the parameters recorded from I902 to I9I 8 for the entire Italian labour force, irregularity seems to be shared by both, although it is more noticeable for the hospitality sector than for the economy as a whole. As for the years I919-1920, it is evident from Tables 2 and 3 that conflicts generally increased substantially in this period. Strikes not only increased in number but they also became longer and harsher, while the number of workers participating in a single strike increased to hundreds or thousands. This hike was particularly marked in the hospitality sector: in 1920, the severity and duration of strikes in this sector went far beyond the national mean.

\section{THE FIRST WAVE OF STRIKES: 1902 AND 1907-1908}

It is possible to highlight the elements that led in each episode to the (partial or complete) defeat or success of the labour mobilization of hotel and restaurant staff, shifting from the observation of quantitative data to the actual conflictual events. When the protest aimed to obtain improvement only for a single category, involved only a part of the labour force in the place where the strike happened, or was directed against specific abuses, it was likely to fail, irrespective of whether the promoter was the union or whether the strike arose spontaneously with either high or low participation. Hotel and restaurant owners easily replaced strikers with relatives or unemployed people available in the location or summoned from outside; often, employees involved in the action returned to work within few days without results.

Some examples will illustrate this pattern. On 4 May 1907, a strike of 200 café and bar boys was proclaimed by the Unione di Miglioramento Caffettieri e Liquoristi in Turin. Strikers demanded 36 hours off each week, a working day of $\mathrm{I} 2$ hours, and the creation of one common employment office. Actual work stoppages, nevertheless, were scarce, and the majority of café and bar employees in the city continued working regularly.

4I. Adriana Lay, Dora Marucco, and Maria Luisa Pesante, "Classe operaia e scioperi: ipotesi per il periodo I 880-I923”, Quaderni storici, 8 (1973), pp. 87-I47, I I I, and I45-I 47; Lorenzo Bordogna and Giancarlo Provasi, "Il movimento degli scioperi in Italia (г 88 I-1973)", in Gian Primo Cella (ed.), Il movimento degli scioperi nel XX secolo (Bologna, I979), pp. 169-304, 200-201, and 2 I I-2 I 2; Arrighi, "Labor Unrest in Italy”, pp. 52-53. 
Table 3. Magnitude, severity and duration of conflicts in the hotel and catering sector in Italy from 1902 to 1923 (in brackets, average data on conflicts at national level).

\begin{tabular}{lccc}
\hline Years & Magnitude* & Severity* & Duration* \\
\hline 1902 & $1,502.6(333)$ & $2.81(13.26)$ & $4,228.6(4,422)$ \\
1903 & - & - & - \\
1904 & - & - & - \\
1905 & - & - & - \\
1906 & - & - & - \\
1907 & $78.8(255)$ & - & - \\
1908 & $84(213)$ & - & - \\
1909 & $12(176)$ & - & - \\
1910 & $73.75(178)$ & $12(11.24)$ & $306.86(3,459)$ \\
1911 & $25.57(308)$ & $1.88(12.03)$ & $32(2,650)$ \\
1912 & $17(220)$ & $5(9.77)$ & $33.33(5,009)$ \\
1913 & $6.66(513)$ & $2(11.56)$ & $74(2,972)$ \\
1914 & $37(259)$ & $1.1(4.84)$ & $29.33(1,437)$ \\
1915 & $26.66(297)$ & $6.04(6.02)$ & $531.5(1,452)$ \\
1916 & $88(241)$ & $2.24(4.85)$ & $558(1,806)$ \\
1917 & $249(372)$ & $2.95(6.28)$ & $225.5(3,195)$ \\
1918 & $76.5(508)$ & $7.94(14.35)$ & $3,001.96(11,932)$ \\
1919 & $377.92(831)$ & $28.49(13.21)$ & $20,363.24(14,768)$ \\
1920 & $714.76(1,118)$ & $9.97(11.29)$ & $9,165.87(7,213)$ \\
1921 & $919.5(638)$ & $6.48(15.44)$ & $116.66(12,030)$ \\
1922 & $18(779)$ & $-(4.48)$ & $-(1,473)$ \\
1923 & $-(328)$ & &
\end{tabular}

Source: Calculations based on: DGS, Statistica degli scioperi avvenuti in Italia; Lorenzo Bordogna and Giancarlo Provasi, "Il movimento degli scioperi in Italia (188 I-1973)", in Gian Primo Cella (ed.), Il movimento degli scioperi nel XX secolo (Bologna, I979), p. 223, Table 6.

Note: From 1903 to 1906 , strikes in the hotel and catering sector were not recorded. For the years 1907, 1908, 1909, and I910, data about lost working days regarding the hotel and catering sector are unavailable.

* Magnitude is the ratio between strikers and strikes; severity is the ratio between lost working days and strikers; duration is the ratio between lost working days and strikes.

Four days later, the strike stopped, and the café and bar boys returned to service without any of these requests satisfied by the owners. The strike had not been supported by most members of the Unione di Miglioramento or by the greater part of the restaurant, coffee-bar, and brewery staff registered with the Camera del Lavoro (approximately 600 people)..$^{22}$ On I August I908,

42. Bollettino dell'Ufficio del lavoro, July 1907, p. I46; the number of strikers is specified in MAIC, DGS, Statistica degli scioperi avvenuti in Italia nell'anno 1907 (Rome, I9I3), p. I44. 
40 waiters' assistants from several hotels in the Lido of Venice, who were not registered with any union, went on strike to obtain a wage increase (their pay fluctuated between 35 and 40 lire a month). The Compagnia Italiana Grandi Alberghi, owner of the establishments in which the strikers worked, laid them off on 2 August, replacing them with new staff from outside Venice. ${ }^{43}$ On ro June I910, 26 out of 65 employees of the café-brewery Gambrinus in Florence left work to protest the three-day suspension of two waiters for a breach of work discipline. The strikers asked for the withdrawal of the suspension, and on I 8 June the rest of the staff joined them. The measure was confirmed, and regular service was resumed on $20 \mathrm{June}^{44}$

In other circumstances, strike action had a positive outcome, depending on whether it was intended to obtain improvements for a specific category of a whole town, or even aimed to reach goals that had positive effects for all workers of the sector, such as free mediation services and a weekly day off. Another favourable factor was when the union succeeded, through a thorough preparation of union activists and the self-organization of the participants, in timing the action to happen close to relevant commercial events or high-season periods. ${ }^{45}$ The above-mentioned strike mobilizations in Florence and Milan in 1902 are well-known examples of such successes.

In Florence on 2 May 1902, proponents of the Lega di Resistenza of cooks, waiters, and café-bar boys presented six demands to the employers (abolition of deductions from the pay of waiters; abolition of private employment agencies; introduction of a minimum wage; a maximum of working hours and a weekly day off for all workers; employment reserved for the residents of the town; and a motion to the municipal and prefecture authorities for the inspection of workplaces to ensure compliance with the current hygiene rules) and asked to discuss them within eight days - otherwise, a general strike would be declared. In the days that followed, representatives of workers and the owners of the hotel and catering establishments met to discuss each demand. The owners delayed the final decision on an overall agreement to a meeting to be held on I3 May. However, only 26 employers of the I I 9 operating in Florence participated in the meeting. Therefore, 647 cooks and waiters decided to protest against this by going on strike. On the morning of I 4 May, the strikers published a manifesto in which they explained the reasons for the protest and apologized for the inconvenience caused to citizens.

43. Il Lavoratore d'albergo e della mensa, August 1908, p. 3; Bollettino dell'Ufficio del lavoro, September 1908, p. 578 .

44. Bollettino dell'Ufficio del lavoro, August I910, p. 290; MAIC, DGS, Statistica degli scioperi avvenuti in Italia nell'anno 1910 (Rome, I912), p. I69.

45. This implies an awareness among the strikers of the impact of their protest on customers and the high effectiveness, even at that time, of work stoppages in the tertiary sector under certain circumstances. For a general consideration of patterns of conflict in the service sector, see Roberto Franzosi, Il gioco delle parti. Attori e azioni nei conflitti di lavoro (Rome, 1994), pp. 40-52. 
From I4 to Is May, many cafés and restaurants stayed closed. In those that were open, the staff consisted of relatives of the owner or workers who were not registered in the Lega. The municipal administration summoned the proprietors of the café-bars, restaurants, and even the hotels to persuade them to reach an agreement with their employees. A total of 8 I owners were present at the meeting. After several debates, some requests were accepted: the introduction of an employment agency free of charges; the abolition of deductions on tips; a weekly day off; and the establishment of a maximum of $\mathrm{I} 2$ working hours in restaurants and $\mathrm{I} 4$ in hotels. As for the minimum wage, it was decided that the unskilled internal staff in hotels and restaurants were to receive 30 lire a month plus board; the internal staff in café-bars and breweries would receive 2.30 lire a day, whereas kitchen staff would be paid 2.50 lire a day. As far as luxury hotels were concerned, waiters would receive 80 lire a month, assistant waiters 50 lire, and porters 35 . In second-class hotels, the wages would be 69, 40, and 30 lire a month, respectively; eventually, in third-class hotels, all waiters would be paid 30 lire and porters 20. A workers' assembly, held the same day, accepted the concessions granted by the owners. On the evening of I6 May, the conclusion of the strike was proclaimed. ${ }^{4}{ }^{6}$

The reasons for the unrest in Milan were more complex. In September I90I, an Associazione per il Collocamento Gratuito fra il Personale d'Albergo, Caffè e Ristoranti (Association for Cost-Free Employment for Hotel, Café and Restaurant Staff) was formed in Milan. Its aim was to provide a free employment service to members (the fee was I lire per quarter) and to foster the improvement of working conditions. Through the Associazione and the Unione di Miglioramento di Cuochi, Camerieri e Affini, the workers exerted pressure on local employers in the following months through petitions and rallies, and began to use the organizations as free-of-charge employment agencies, thus circumventing the established private mediators and agencies. From February to April 1902, there were several meetings between workers' and owners' representatives to reach an agreement on a common office of employment without fees. However, due to the opposition of hoteliers and restaurateurs to the project, the efforts were in vain. The former, in particular, feared this office would put the control of the labour supply into the hands of socialist unionists and that this would negatively affect the "quality" of the staff available. On 29 May, the Unione sent them an ultimatum: if the owners of the hospitality establishments did not accept by June 3 the creation of a common employment office without fees (consisting of representatives of the employers and

46. "Lo sciopero dei camerieri, cuochi, caffettieri ed affini”, La Nazione, is and I6 May i902, pp. I-2; Il Cameriere, 20 June 1902, p. 4; MAIC, DGS, Statistica degli scioperi avvenuti nell'industria e nell'agricoltura durante gli anni 1902 e 1903 (Rome, I906), p. 55. 
employees); the abolition of deductions from tips; the introduction of a weekly day off; a maximum of working hours; and a minimum wage for internal staff, the hotel, restaurant, and cafè workers would proclaim a strike. Following a negative response from the SIA section of Milan and the restaurant owners, on 7 June, 6,500 employees refused to work. ${ }^{47}$

Because some businesses had remained open thanks to the help of owners' relatives and workers not enrolled in the unions, violent clashes occurred between strikers, on the one hand, and crumiri (strike-breakers) and owners, on the other. On 8 June, approximately Ioo demonstrators assaulted the managers and employees of a hotel and a restaurant in the centre of Milan. After the police had been informed, two of the attackers were arrested after a minor brawl. A waiter who had joined the protest entered a brewery and offended customers and employees; the latter physically assaulted him and he was arrested by police officers. ${ }^{48}$ After discussions between the committees of strikers and owners (who feared the flight of customers from the city due to the disorder) and thanks to the intermediation of the Prefect, the strike came to an end on Io June and an agreement was signed. This agreement established the creation of a free employment service funded by both parties and directed by three workers, three employers, and a person chosen by the Chamber of Commerce; the introduction of two days off a month for all employees; the abolition of deductions from tips; a fourteen-hour service maximum; and a minimum wage of 45 lire a month for internal staff. ${ }^{49}$

Such results, nevertheless, rarely became consolidated. Where agreements were achieved after hard struggles, it was often difficult to have them enforced. In the summer of 1902 , the militant activists in Milan and Florence, for example, complained that the arrangements were not put into practice. On the one hand, several owners refused to use the joint employment office and continued to charge fees to waiters; on the other, many waiters did not make use of the weekly rest day because they considered it a loss of earning opportunities. ${ }^{\circ}$ In May i 903 , the Milan section of SIA and the association of restaurant and café owners declared the agreement of June 1902 null and void and stopped funding the employment

47. “Associazione pel collocamento gratuito”, Il Cameriere, is September I90I, pp. I-2; Gallazzi, "Lotta di classe”, p. 2; Relazione dell'ispettore di Pubblica Sicurezza Allone sullo sciopero di cuochi, camerieri ed affini, Milan, ı० August 1902, Archivio Centrale dello Stato, Roma [henceforth, ACS], Presidenza del Consiglio dei Ministri, Materie, I902, b. 265, fasc. 8/ı; DGS, Statistica degli scioperi avvenuti nell'industria e nell'agricoltura, p. 32.

48. "Lo sciopero dei camerieri", Corriere della Sera, 9 June I902, p. 3.

49. Relazione dell'ispettore di Pubblica Sicurezza Allone; E. Benedetti, "Ai krumiri mascherati", Il Cameriere, 20 June 1902, p. 2.

50. "I nostri padroni", Il Cameriere, is July 1902, p. 2; miscellaneous news published in the section "Corrispondenze", ibid., is August 1902, p. 3; Relazione dell'ispettore di Pubblica Sicurezza Allone. 
office, which, because the Unione di Miglioramento dei Camerieri had too few economic resources, ceased functioning some months later. ${ }^{5 \mathrm{I}}$

But also for the workers themselves it was difficult to abide by the agreement. The structure of the labour market, characterized by a high dependence on season, an imbalance of supply over demand (generating unemployment), and the replaceability of unskilled jobs, contributed to the perpetuation of differences between internal and external staff and made it difficult for the workers to respect the signed agreements. In addition, both FILAM (as shown in Table I) and the SIA had relatively few members compared with their respective constituencies. ${ }^{52}$ Although they were engaged to varying degrees in the conflicts and in the discussions between the two associations, most employees and employers did not feel obliged to conform to the deals these associations had reached when they believed these deals did not fit their needs. A substantive indication of this was the recurrent dysfunctionality of the employment offices created both by the labour movement and by the SIA in some cities of the north and centre from I 90 I to World War I. Notwithstanding the thousands of workers who had found a job through these offices, both worker associations and hotel owners complained about the limited use of them by their members and were forced to acknowledge that the competition of private mediators and employment agencies with fees was still very strong. ${ }^{53}$

Nevertheless, despite these difficulties, uneven results with regard to the participation of workers, numerous defeats, and only very little improvements obtained from employers (and these only with much effort), an awareness of the needs of this group of workers and their ability to mobilize had grown in the course of the struggles waged by the workers and by their unions. While the conflicts described still reflected a different situation for hotel and restaurant staff, and distinct forms of self-identification compared with industrial workers, subsequent developments indicate a

5. Il Lavoratore della mensa, is May 1903, p. 2; Gallazzi and Premoli, "La disoccupazione tra i lavoratori della mensa", p. 3 .

52. In 1908, there were 478 members of SIA, but, according to an estimate of the time, there were 2,250 small, medium, and large hotels in the Italian holiday resorts; see "Gli Alberghi in Italia e in Svizzera”, Rivista degli alberghi, I I July 1908, pp. I-2; ibid., I 8 January I909, p. 4.

53. From I90 I to I9I I, the employment offices of SIA (after the office in Genoa, new ones had opened in Florence, Rome, and Naples) had procured jobs for I 2,545 employees, but their service was still considered inadequate by hotel owners; see Rivista degli alberghi, 3 July I9I I, p. 2; ibid., 8 December I9I3, p. 3. From 1902 to 1903 , an employment office without fees of the Lega di Resistenza in Venice had procured a job for about only 100 employees because of a boycott by the hoteliers; another office of this kind, created in Rome in spring 1908, had been forced to close in January I 909 due to the low level of enrolment of unemployed people in this category. See Luigi Geremia, "L'ufficio di collocamento gratuito e la questione delle marche", Il Lavoratore della mensa, is May I903, p. 4; Il Lavoratore d'albergo e della mensa, May 1908, p. 4; ibid., February I909, p. 3. On the few results of the union employment offices without fees in these years, see Giovanni Nicola, "Mutualità e sfruttamento", ibid., is January I9I4, p. 2. 
change in the outlooks, demands, and behaviour of this group of workers during the first fifteen years of the twentieth century. Strikes, one might argue, in view of the increasing incidence of work stoppages in this period, played an important role in this process: through strikes, waiters, cooks, and porters began, in a difficult and convoluted way, to see themselves more in the image of industrial workers than as, for example, servants or selfemployed mini-entrepreneurs. ${ }^{54}$ This process culminated during the biennio rosso of 1919-1920.

\section{THE SECOND WAVE: THE STRIKES OF 1919-1920}

Unlike the pre-war period, the protests of the years I919-1920 were organized and led in all locations by sections of the FILAM, and the demands that were put forward followed the programme worked out and adopted by the National Congress of the union held in Florence from 22 to 24 April r919. At the end of May 1919, FILAM - stimulated by the significant increase in the number of members, and by the example of industrial trade unions joining CGdL, which in those months had demanded and achieved the eight-hour working day and the introduction of collective agreements - proceeded to submit to SIA a draft for a national collective agreement. In the draft, in addition to twenty-four hours off per week and free employment offices run jointly by employers and workers, a limitation of work shifts to eight hours was called for, together with collective agreements as a way of regulating employment relationships and, above all, minimum wages for both internal and external staff, and the replacement of tips with fixed pay or a percentage of takings. ${ }^{55}$

The possibility of maintaining or abolishing gratuities as compensation for service had been discussed by both hotel owners and serving staff since the beginning of the century through to the postwar period. As in other European countries and in the United States, union organisers, journalists, and the public noted that tips generated servile and humiliating attitudes among waiters and porters towards customers and fostered their selfexploitation, the illusion of being partners and not employees, and the separation from those workers in the sector who did not receive gratuities. All involved acknowledged that it was difficult to abolish tipping because hotel and restaurant customers were used to it (while complaining about it), waiters deemed it a flexible means of increasing their income, and owners

54. The important role of strikes in the organizational development of the Italian labour movement from the end of nineteenth century to World War I is also highlighted in Adolfo Pepe, Classe operaia e sindacato. Storia e problemi (I 890-1948) (Rome, I982), pp. 2 I 3-225.

55. Mazzi, “Adunata!", Il Lavoratore d'albergo e della mensa, 28 February i919, p. I; "Intorno al contratto di lavoro", Rivista degli alberghi, 9 September 1919, p. I; Famiglietti, Le origini dell'attività sindacale nel settore dei servizi, pp. I 2 I-I 24. 
considered it a useful instrument for keeping labour costs down. ${ }^{6}$ In spring I919, however, disputes in several cities in central and northern Italy succeeded in replacing tips with a variable percentage on bills in catering establishments (an idea already proposed by some hoteliers shortly before World War I).

FILAM welcomed these developments and supported them without hesitation, so that, as one high state official noted, "the tip is abolished in the whole of Italy and is replaced with a compensation method that does not diminish at all the current earnings of hotel and restaurant employees". 57 After heated debates between the representatives of the two parties in several meetings, on 2 June I9I9, FILAM and SIA signed an agreement in Rome which, in fact, meant that the draft proposed by FILAM was accepted and its stipulations were to take effect on I July. However, possibly counting on the well-known inability of the trade union on previous occasions to enforce measures settled upon, the owners declared in the following months that they would not abide by the agreement, especially the abolition of gratuities (they justified this by pointing to the disagreements among employees on the convenience of abolishing it) and the adoption of the eight-hour work day (they said they would wait for a legal regulation on this issue in Parliament). ${ }^{58}$ Consequently, the union activists felt free to resort to strike action to ensure measures already achieved, if only on paper.

From February to April 1920, strikes by hotel and restaurant staff occurred in several Italian towns, including some in the south. They all shared the same demands (an eight-hour work day; the abolition of tips and the adoption of fixed wages for waiters and porters or a percentage on bills; the establishment of a minimum wage; the establishment of free

56. For varied contemporary voices on the question of gratuities see "La questione delle mancie", Il Lavoratore d'albergo e della mensa, I October 1906, pp. 2-3; Luciano Ferro, "Aboliamo le mance", ibid., January 1909, pp. 3-4; Mazzoni, "Il pourboir", ibid., 24 March I9I4, p. I; "Le mancie negli Alberghi", Rivista degli alberghi, 8 November I909, p. I; Giovanni Benettini, "Pro e contro le mancie”, ibid., 4 April ı 9ro, p. 2; Guido Cosattini, "Ancora sul tema delle mancie”, ibid., is July i9i 2, p. I. About the debates and the initiatives taken by trade unions, employers' associations, and opinion makers to abolish or maintain gratuities outside Italy from the beginning of the twentieth century to the years after World War I, see Segrave, Tipping, pp. 25-44, and Van den Eeckhout, "Waiters, Waitresses, and their Tips".

57. Telegramma del Prefetto di Milano al Ministero dell'Interno, i September 1919, ACS, Ministero dell'Interno, Direzione Generale di Pubblica Sicurezza, Affari Generali e Riservati [hereafter, MI DGPS AGR], I9I9, b. 70, fasc. "Convegno rappresentanti Comitati regionali della Fed. ne Naz.le Personale albergo e mensa”. All translations from Italian are mine. On the earlier entrepreneurial proposals to replace tips with variable percentages on takings, see "Referendum sulla questione delle mance", Rivista degli alberghi, 26 August I91 2, pp. 2-3; Guido Cosattini, "Per l'abolizione delle mancie [sic] al personale d'Albergo", ibid., 9 December 191 8, p. 2.

58. "Il contratto collettivo di lavoro", Rivista degli alberghi, i8 August 1919, p. I; "Intorno al contratto di lavoro", p. I. 
employment services; a weekly day off; and compulsory accident insurance). Notwithstanding the usual efforts to counter these strikes by the employers (the use of relatives and the search for strike-breakers to keep establishments open), many of them ended successfully for the workers, although the eight-hour work day was rarely obtained. 59

The strike wave kept growing and reached its peak between early May and late June, with major strikes in Bologna, Genoa, and Milan. The duration of the struggles in these three cities was particularly long ( 32 days in the first, 27 in the second and 53 in the third), participation was high (600 strikers in Bologna, 3,000 in Genoa, and 5,000 in Milan) and workers frequently resorted to violence. Attacks on open shops and assaults on strike-breakers occurred in these places as they had in Milan in 1902, even more so as the most important hotels and bars were protected by police cordons. Furthermore, cooks, waiters, and porters organized surveillance teams that walked through the urban centres to check how many and which hotels, restaurants, and cafés stayed closed and to force those that were open to comply with the work stoppage. These practices are in themselves remarkable as they implied the adoption of methods of maintaining discipline among strikers that had already been tried and tested in other sectors and other countries. ${ }^{60}$

In Bologna and Milan FILAM managed to win the solidarity of other workers, such as bakers, butchers, errand boys, laundry-men, orchestral players, and street cleaners, who also decided to go on strike to force hoteliers and restaurateurs to accept the demands of the workers in the hospitality business. Finally, the struggles intensified because the trade union demanded the creation of Commissioni Interne (work councils) in workplaces, consisting of two to five employees (depending on the size of businesses) that aimed to check the enforcement of agreements and to act as permanent representative bodies of the workers towards the employers - a demand which had been adopted from strikers in factories. ${ }^{6 \mathrm{I}}$ The hoteliers strongly opposed this demand, aware that such a concession would imply a challenge to their authority and their freedom of action vis-à-vis the workforce. Through the mediation of the Prefects, the disputes ended with

59. For more detailed reports see "Agitazione del personale", Rivista degli alberghi, 28 March I920, p. 3; "Le agitazioni del personale”, ibid., 4 April I920, p. I; Bollettino del lavoro e della previdenza sociale, June 1920, pp. 629-63 I and 645; ibid., July-August I920, pp. 30 and 47-48. 60. Jeremy Brecher, Strike! (Greenwich, CT, 1974), passim; Pepe, Classe operaia e sindacato, pp. 279-282.

6r. Commissioni Interne (Internal Commissions), institutions similar to other bodies for the collective representation of workers within companies, were elected by the employees to act on their behalf towards the employers and to supervise the enforcement of agreements signed by the two parties. They were first established in the years before World War I in some large Italian industrial plants after a series of militant labour mobilizations. See Barbadoro, "Lo sviluppo del movimento sindacale in Italia”, pp. $5 \mathrm{I}-54$. 
deals providing for a weekly day off; the replacement of tips with a fixed percentage of customer bills (from Io to 20 , depending on the locations); minimum wages for all staff; accident insurance paid by employers; the creation of a free employment office run by the two parties; the presence of a shop steward within the businesses supervising the fair distribution of the percentage to employees and the enforcement of agreements; eleven-hour work days in bars, cafés, and restaurants; and ten hours of worked time plus one hour of "presence" in hotels. ${ }^{62}$

In view of the difficulties in achieving significant improvements in earlier mobilizations, it is surprising that FILAM was so determined and capable of resisting the strong opposition of the employers, leading to a wage rise and several regulatory advances for this group of workers. Many factors contributed to this result. First, the strikes of 1919-1920 occurred in large urban centres and not in small resorts on the coast. As indicated by a case study about San Sebastián in Spain, a strike of seasonal workers in the hospitality sector in places outside the major cities rarely succeeds in involving other forces of the labour movement. Furthermore, if the place is known and cultivated as a luxury resort for the affluent it seems all the more difficult to build up a substantial movement, as many actors involved (including many workers) want to keep up the image of tranquillity and security. ${ }^{63}$

Second, in the biennio rosso, the massive mobilization of industrial and rural workers by the leftist trade unions was able to achieve truly remarkable improvements in terms of wages and working conditions. Thus, the hospitality and catering workers of the main cities of the peninsula and their union organization benefited from the climate of permanent social conflict, providing extra resources and the stimulus for protracted struggles. Also, this context made it easier to gain the support and solidarity of other sectors of labour, sectors that had previously looked with suspicion or indifference on waiters and their colleagues. ${ }^{64}$

Third, while journalists and employers were still denouncing the high incomes of waiters (pointing to abundant tips and the considerable differences between hotel employees and restaurant and café employees), the

62. For circumstantial reports on the strikes, see Bollettino del lavoro e della previdenza sociale, September-November 1920, pp. 272-273; the telegrams and reports of the Prefect of Bologna to the Home Office, Io and 27 May 1920, ACS, MI DGPS AGR, 1920, b. 62, fasc. "Bologna Agitazioni varie"; of the Prefect of Genoa, I2, 17 and 21 May, I and 26 June 1920, ibid., b. 68, fasc. "Genova - Agitazioni varie"; of the Prefect of Milan, I2, I6, I9, 2 I , 25, 26, 27, and 3I May, 8, I0, I I, I 2, I4, I 5, I6, and 27 June 1920, ibid., b. 7I, fasc. "Agitazioni personale alberghi e mensa".

63. Walton and Smith, "The Rhetoric of Community and the Business of Pleasure", pp. 26-30.

64. On the characteristics and the intensity of the struggles during the "biennio rosso" in Italy, see Giuseppe Maione, Il biennio rosso. Autonomia e spontaneità operaia nel I9I9-I920 (Bologna, I975), pp. 7-39, 9I-I 29, and 216-268; Roberto Vivarelli, Storia delle origini del fascismo. L'Italia dalla grande guerra alla marcia su Roma, 2 vols (Bologna, I99I), II, pp. 502-535, 592-645, and 760-910. 
income realities had profoundly changed. ${ }^{65}$ The sharp rise in prices that occurred immediately after the war in Italy had also eroded the earnings of those who served at table, assisted tourists, or carried their luggage. Because of the increasing cost of living, customers became less generous than in the past, and, at the same time, consumer goods became more expensive. Due to the rising instability of earnings, proposals to abolish gratuities and replace them with wages or fixed percentages on bills, and to extend the weekly day off, and shorten working hours seemed a good solution to those working in the hospitality sector. This persuaded many to join FILAM and to participate in strikes to far a greater extent than before the war. ${ }^{66}$

Finally, the inflexibility demonstrated by hotel, restaurant, and café owners in dealing with the disputes made the conflict harsher. This was partly based on their belief that their employees were not able to build up sufficient pressure for far-reaching changes in labour relations and the organization of work, and on the view that saw hotel and restaurant staff as more (subordinate) partners than workers. In doing so, employers in the hospitality sector showed the same attitude as their colleagues in other sectors, especially in industries that until then had experienced little labour unrest and in which a patriarchal and paternalist outlook had prevailed, striving for the harmonious cooperation of different social groups. ${ }^{67}$

65. For the persistence of the "old" image see, for instance, "La questione delle mance", Rivista degli alberghi, 2 September 1919, p. I; "I camerieri e le mance”, ibid., 23 September 1919, p. 3; "Lo sciopero dei camerieri", Corriere della Sera, I6 June I920, p. 3; "I lavoratori della mensa", Il Resto del Carlino, 22 May i920, p. 2.

66. Taking the figure of $\mathrm{I} 9 \mathrm{I} 3$ as $\mathrm{I} 00$, the cost of living index in Italy reached 268 in 1919 and 352 in 1920. Owing to the strikes and the unrest of the workforce in those years, the real wages of workers and the budgets of their families succeeded in coping with the rise of inflation. There are no available data on the national average pay of hotel and restaurant staff, but some evidence suggests that the wages of waiters and porters were not so different from those of industrial workers. It has been estimated that the average daily wage of an Italian industrial worker in 1920 was equal to I 3.66 lire. According to the collective agreement signed in Rome on 28 March of that year between FILAM and SIA, a maître in first-category hotels (not luxury) of the capital city could collect no less than io lire a day, a porter no less than 8.33 lire, and a kitchen hand no less than 13.33 lire. See Bollettino del lavoro e della previdenza sociale, June 1920, p. 629; Vera Zamagni, “Industrial Wages and Workers' Protest in Italy during the 'Biennio Rosso' (1919-I920)", Journal of European Economic History, 20 (1991), Pp. I37-I 53, I40-I 48.

67. For a sample of employers' stances see: "Camerieri d'Albergo che fanno sciopero", Rivista degli alberghi, I6 September 1905 , p. I; "A proposito dell'agitazione attribuita ai cuochi, camerieri ed altro personale d'albergo", ibid., I6 January I907, p. I; Virgitti, "Les Rapports entre Hôteliers et employés", ibid., 28 December I 908, p. 2; "Proprietari d'albergo e personale”, ibid., 3 February I919, pp. 2-3; "L'agitazione del personale", ibid., I 4 March 1920, p. I. On the attitude of Italian employers towards strikes from the end of the nineteenth century to the advent of fascism, see Gian Carlo Jocteau, L'armonia perturbata. Classi dirigenti e percezione degli scioperi nell'Italia liberale (Rome [etc.], I988), pp. 179-229. 
Unfortunately, many outcomes reached during the biennio rosso did not last long. Owing to a sharp decrease in strikes and mobilizations (at national level) from September I 920 onwards, the creation of fascist union organizations that were far more compliant with the owners than the socialist ones ${ }^{68}$ and increasing unemployment in the sector since 1921, ${ }^{69}$ employers felt the tide turning. The failure of important strikes in I 92 I was a signal that things had changed. On 25 January of that year, approximately 7,000 hotel, restaurant, and café employees in Rome refused to work. One month earlier, FILAM had petitioned the local section of Associazione Italiana Albergatori (AIA, the new name that SIA had adopted in the meantime) for wage increases of more than Ioo per cent and working shifts of 8 hours maximum for internal staff. After the owners of hospitality establishments had refused these demands, the workers went on strike. However, many establishments were able to replace strikers with other workers (recruited from the pool of casual labourers that had swollen with rising unemployment), and the employers stated that they would only be able to offer pay raises of between 40 and 70 per cent. On 8 February, the number of strikers dropped to 2,000 and, two days later, regular service resumed in the capital city. Of those workers who had participated in the action, a few hundred remained without employment. ${ }^{70}$

In another mobilization at the end of June $192 \mathrm{I}$, a large proportion of hotel staff in Trieste went on strike because the hotel-owners did not respect some points of the agreement signed the previous year (namely, the role of a shop steward in monitoring the observance of the agreement, the use of a unioncontrolled employment office when hiring, and the percentage on bills not separated from the rest of the items listed). Although the strike lasted more than a month, the hoteliers did not give in. In the first days of August, a new agreement was signed, according to which the shop steward would only be authorized to check the distribution of the percentage on bills among the employees, the employment service would be in the hands of a municipal office, and the percentage for service would be shown separately on customer bills. Also, many strikers were not allowed to return to their workplaces. ${ }^{71}$

68. In Milan in I92 I, the Sindacato Nazionale Impiegati Albergo e Mensa was founded by fascist activists; it enlisted I,600 members from the start; Bollettino del lavoro e della previdenza sociale, July i 922 , p. 55 .

69. According the Ministry of Industry, Commerce and Labour, the unemployed of the branch "commercial businesses" (hotels, restaurants, bars, bakeries, patisseries, and barbers' shops) who were registered in various free employment agencies grew from 3,668 in April I92 I to I0,35 I in October 1921, and to 10,804 in February 1922. The number of unemployed was published monthly in Bollettino del lavoro e della previdenza sociale.

70. Rivista degli alberghi, 27 February I 92 I, p. 4; Bollettino del lavoro e della previdenza sociale, June I92I, pp. $575-576$.

7I. "Lo sciopero di Trieste", Rivista degli alberghi, I7 July I 92 I, p. 2; "Lo sciopero dei lavoratori della Mensa a Trieste. Un'altra vittoria della nostra classe”, ibid., I4 August I92 I, p. I. 
Events such as these were both a symptom and a cause of an increasingly weakened labour movement, setting off dynamics often seen in such situations: increasing numbers of employees were no longer members of FILAM, and fewer workers could be mobilized into action against employers.

As shown in Tables I and 2, in 1922 the numbers of strikers and members of FILAM plummeted compared to the previous three-year period. 1922 also saw violent attacks by fascist squads on the officials and infrastructures of the union organization. In Venice, the local secretary of FILAM was beaten up by fascists; in Genoa, the cooperative café was attacked and destroyed; and in Milan, Florence, and Brescia, the union offices were devastated. Eventually, the house of the National Secretary, Ercole Viganò, was ransacked and his family threatened. At the same time, AIA began signing labour agreements with the fascist union, as happened in Milan in July, excluding the CGdL from the negotiations, and concluding in results favourable for the employers, such as an extra hour of work and the abolition of joint employment offices. Under these circumstances, it is not surprising that the Central Committee of FILAM stepped down in December 1922 leaving the organization without a central structure and thus, de facto, dissolving it. The next year, the only remaining section was the one in Milan (with 3 Io members) and no strikes by hotel and restaurant staff in the whole of Italy are recorded for $1923 .{ }^{72}$ Following the data available, cooks, porters, waiters, and other workers in the hospitality sector would enter into strike action again only in $1946 .{ }^{73}$

\section{CONCLUSIONS}

The history of conflicts promoted by hotel, restaurant, and café staff in Italy highlights several similarities and some differences between workers in the hospitality sector and those in other sectors - similarities and differences relating to the constitution of the labour market, union organization, and methods of struggle.

72. On the fascist attacks see "L'agitazione del personale d'albergo", Il Lavoratore d'albergo e della mensa, Io September 1922, p. 2. On the dissolution of FILAM see Famiglietti, Le origini dell'attività sindacale nel settore dei servizi, pp. I 27-I 29.

73. For 1923 there are indeed no records of any strikes by employees of hotels, restaurants, and bars. After that, data collection on labour conflicts for all sectors was entirely suspended from I 924 to 1949. Obviously, this does not mean that waiters and cooks went into full hibernation for such a long time without any contentious activities whatsoever. Even if under the fascist regime strikes were banned and the fascist trade union was the only one authorized to exist, the discontent of the labour force expressed itself through fascist union representatives and numerous petitions to public authorities. It is likely that there were collective protests beyond the control of fascist trade unions between 1925 and 1945 , but this would have to be investigated in future studies by close examination of police documents. 
The abundance of labour supply, the segmentation of professional positions and of pay, the fragility of representative bodies, and the irregularity of strikes were issues common to catering and hospitality staff, on the one side, and industrial and rural workers, on the other, from the early twentieth century to the advent of fascism. Also, in the period immediately after World War I, almost all groups of workers shared a wide consensus on a need for and importance of trade unions; this led, in all sectors of the economy, to widespread and intense labour unrest, resulting in unprecedented wage rises and legal advances, which substantially improved a hitherto unfavourable employment structure. The main factors that led to the outbreak of strikes were thus similar for hotel and restaurant workers as for their colleagues in factories and in agriculture. As can be deduced by comparing Tables I and 2, enrolment numbers in trade unions were a major factor in the proclivity to strike. ${ }^{74}$

At the same time, there were characteristics that were more specific (though not exclusive) to workers in the hospitality sector: sharp seasonality; instability and high geographical mobility of employment; numerous divisions among the workers (due not only to the typology of jobs but also to ideas held by employers and public opinion regarding the nature of jobs in the hospitality sector). These led union activists, for most of the years considered here, to be cautious and to start strikes only when they were sure of having the support of a sufficient number of workers both inside and outside the union. It was probably also for this reason that the strongest explosions of conflict among this group of workers occurred during the same period in which there were intense social clashes in the whole of Italy.

During the period analysed, hotel, café, and restaurant employees became acquainted with methods of collective bargaining with the owners of hospitality establishments (the formulation of a set of goals; a manifesto including formal demands; meetings with the employers to sign an agreement; in the case of faltering negotiations, the proclamation of a strike), and the methods of struggle already tried and tested by factory workers and other labourers. They also learned and put into practice actions typical of the tertiary sector, which were intended to cause serious damage to owners while simultaneously trying to avoid alienating too many of the immediate users of the service, that is, the customers. Workers in the sector thus deployed a broad array of actions.

In the course of the strike of Bologna on I 6 May I920, for example, I00 waiters acted as customers at a city centre café; they arrived together and consciously overloaded its handling capacity by all placing the same order to the owner, who managed the business with his family. The next day, they did it again in a trattoria. ${ }^{75}$ On the other hand, both before and after World

74. Bordogna and Provasi, "Il movimento degli scioperi in Italia", pp. 193-195.

75. See also "Le strane dimostrazioni dei camerieri scioperanti", Il Resto del Carlino, i 8 May I920, p. 2. 
War I, strikers often made public announcements in which they apologized for the inconvenience caused by their protests. Conversely, strikers sometimes chose days for work stoppages that were close to events or seasons that attracted many clients to the hospitality establishments. ${ }^{76}$ When employers did not move, workers would resort to more coercive and violent action to frighten patrons and to discourage them from coming to the cities.

In general, the strikes were likely to be successful (although achievements did generally not last long) when activists succeeded in becoming spokesmen for the aspirations of both internal and external staff. As evidenced by the unrest of 1902-1907/1908 and 1919-1920, the former mainly aimed for a reduction of working hours, minimum wages, and a weekly day off; the latter aspired to income stabilization (either through the abolition of deductions from tips or by replacing them with fixed percentages of customer bills) and access to a free employment service.

An examination of the conflicts of Italian hotel and restaurant employees from a quantitative and descriptive perspective is, obviously, not enough to provide a complete picture of this group of workers. Many fields of research remain to be investigated, such as the cultural importance of gratuities in shaping the attitudes of workers, or the role of legal regulations on hotel and catering activities in influencing trade-union action. For this, other sources should be explored, from literary ones to juridical ones. The intention of this article has been, on one hand, to connect the analysis of the Italian case to some of the concerns raised in studies on the history of labour markets as well as the history of waiters, cooks, and porters in other European countries and in the United States. On the other hand, it is intended to enhance the range of these studies by focusing on a neglected aspect of the history of workers in the hospitality sector: namely, the strike actions of the entire group of workers in the sector and how these functioned as means of unionization and a medium of the changing (self-)perception of the workers.

In the period between the first years of the twentieth century and the advent of fascism, hotel and restaurant employees in Italy adopted modes of struggle that were partly original and partly analogous to those of other Italian workers. Despite circumstances that, in general, dissuaded them from entering into labour conflict (strong differences in systems of pay and working conditions, cultural stereotypes fostered by employers and opinion makers, and the weakness of unions), many waiters, cooks, porters, and other workers in the sector, began to organize, mobilize, and enter into conflict. Starting from the decades in question, strikes, unrest, and petitions

76. In the immediate postwar period, this tactic was adopted with quite good results. See "Senza camerieri”, Corriere della Sera, 7 June I9 19, p. 3 ; "Lo sciopero dei camerieri”, ibid., I 3 June I 919 , p. 4; "Lo sciopero dei lavoratori della mensa", Il Secolo XIX, 23 May I920, p. 2. 
were important moments and mediums of the process in which they questioned deferential behaviour towards bosses and customers, on the one hand, and divisions between internal and external staff, on the other. Over time, they increasingly progressed towards being "real" workers, i.e. a group of labourers with attitudes and behaviours similar to those attributed to the prototypical industrial working class.

\author{
TRANSLATED ABSTRACTS \\ FRENCH - GERMAN - SPANISH
}

Paolo Raspadori. Devenir des travailleurs? Grèves du personnel de l'hôtellerie et de la restauration en Italie (I902-I923).

Pendant longtemps, les conditions de travail et les conflits de travail des employés du service dans l'hôtellerie et la restauration n'ont pas été au centre de l'attention des historiens du travail, particulièrement en Italie. Cependant, depuis la fin des années I 800, un nombre considérable de cuisiniers et de serveurs dans les villes commencèrent à s'organiser pour améliorer leurs conditions de travail et pour créer des formes alternatives sans frais de placement. Depuis le début des années 1900, les syndicats des employés de l'hôtellerie et de la restauration (groupés dans une Fédération Nationale en 1907) tentèrent d'atteindre ces objectifs par des grèves et des manifestations, dont certaines furent extrêmement militantes. Utilisant une vaste gamme de sources primaires et de données quantitatives, cet article, premièrement, décrira les caractéristiques des conditions de travail des travailleurs dans l'hôtellerie et la restauration en Italie; deuxièmement, il analysera l'évolution des organisations, des revendications et de l'action de grève conduites par ce personnel depuis le début du vingtième siècle jusqu'à la montée du fascisme. Distinguant deux vagues de mobilisation (1902-I907/ I908 et 1919-1920), cet article vise d'une part, à souligner les différences et les ressemblances entre des actions syndicales des employés de l'hôtellerie et de la restauration par rapport à celles des travailleurs industriels et ruraux et d'autre part, à se concentrer sur les manières dont les grèves incitèrent les travailleurs à avoir l'impression d'être de "réels" travailleurs en termes de perspective et de comportement de travailleurs industriels.

Traduction: Christine Plard

Paolo Raspadori. Arbeiter werden? Streiks von Beschäftigten des Hotel- und Gastgewerbes in Italien (1902-1923).

Die Arbeitsbedingungen und arbeitsbezogenen Proteste von Dienstleistungsangestellten in Hotels und Gaststätten standen lange Zeit nicht im Mittelpunkt der Aufmerksamkeit von Arbeitshistorikern. Dies gilt insbesondere für Italien. Ab Ende des I 9 . Jahrhunderts begann sich jedoch eine beträchtliche Zahl von Köchen und Kellnern in italienischen Städten $\mathrm{zu}$ organisieren, um die eigenen Arbeitsbedingungen $\mathrm{zu}$ 
verbessern und alternative, kostenlose Formen der Arbeitsvermittlung zu schaffen. Zu Beginn des 20. Jahrhunderts versuchten die (ab 1907 in einem landesweiten Verband zusammengeschlossenen) Gewerkschaften der Beschäftigten im Hotel- und Gastgewerbe, diese Ziele durch Streiks und Demonstrationen zu erreichen, die mitunter bemerkenswert militant waren. Der Artikel beschreibt zunächst, unter Verwendung eines breiten Spektrums an Primärquellen und quantitativen Daten, die Arbeitsbedingungen der Beschäftigten im italienischen Hotel- und Gastgewerbe; anschließend wird die Entwicklung der entsprechenden Organisationen, Forderungen und Streiks vom Beginn des 20. Jahrhunderts bis zum Faschismus nachgezeichnet. Dabei werden zwei Mobilisierungswellen unterschieden (I902-1907/08 und 1919-I920). Der Artikel soll zum einen die Gemeinsamkeiten und Unterschiede zwischen den gewerkschaftlichen Aktionen der Hotel- und Gastgewerbeangestellten einerseits und der Industrie- und Landarbeiter andererseits aufzeigen. Zum anderen soll das Augenmerk darauf gerichtet werden, wie die Streiks der Dienstleistungsangestellten dazu beitrugen, dass sie sich als "richtige" Arbeiter zu fühlen begannen, deren Anschauung und Verhalten denen der Industriearbeiter ähnelten.

Übersetzung: Max Henninger

Paolo Raspadori. ¿Convirtiéndose en trabajadores? El movimiento buelguístico del personal de hoteles y restaurantes en Italia (1902-I923)

Durante largo tiempo las condiciones de trabajo y la conflictividad laboral de los empleados en el servicio de hoteles y restaurantes no han sido objeto de atención por parte de los historiadores del trabajo, especialmente en Italia. Sin embargo, desde finales del ochocientos observamos que un considerable número de cocineros y camareros italianos comenzaron a organizarse en las ciudades con el objetivo de mejorar sus condiciones laborales y de idear formas alternativas de colocación laboral que no implicaran coste alguno para ellos. Desde los primeros años del siglo XX, las organizaciones sindicales de los empleados de hoteles y restaurantes (agrupados de forma conjunta en el seno de una Federación Nacional a partir de 1907) intentaron alcanzar sus objetivos mediante la convocatoria de huelgas y manifestaciones, algunas de las cuales destacan por su intensa combatividad. Contando con un amplio abanico de fuentes primarias y de datos cuantitativos este artículo describirá, en primer lugar, las características principales de las condiciones laborales de los trabajadores de hoteles y restaurantes en Italia. Posteriormente pasará a analizar la evolución de las organizaciones, sus reivindicaciones y las acciones de lucha emprendidas por este tipo de empleados desde los inicios del novecientos hasta el advenimiento del régimen fascista. Distinguiendo dos olas de movilización (1902-1907/1908 and 1919-1920) este artículo permite, en primer lugar, resaltar las similitudes y diferencias entre las acciones sindicales de los trabajadores de hoteles y restaurantes comparándolas con aquellas desarrolladas por trabajadores en el ámbito rural e industrial; por otro lado, el texto también permitirá analizar en la manera en que las huelgas inducían al personal de servicio sentirse como trabajadores "de verdad", es decir teniendo perspectivas y actitudes semejantes a las de obreros industriales. 